\title{
Marine snow aggregates: life history sequence and microbial community of abandoned larvacean houses from Monterey Bay, California
}

\author{
P. J. Davoll* \& M. W. Silver \\ Institute of Marine Sciences, University of California, Santa Cruz, California 95060, USA
}

\begin{abstract}
Abandoned larvacean houses and unfiltered sea water were sampled using SCUBA techniques from near-surface waters of Monterey Bay, California during different phases of the seasonal upwelling period. Concentrations of 5 trophic and size categories of microorganisms found on these aggregates, i.e. bacteria, autotrophs with equivalent spherical diameters both $<5 \mu \mathrm{m}$ (biovolume $<65 \mu \mathrm{m}^{3}$ ) and $>5 \mu \mathrm{m}$ (biovolume $>65 \mu^{3}$ ), heterotrophic flagellates and ciliates, were greater than surrounding water values by factors of $10^{2}$ to $10^{3}$. Measured differences among house aggregates led us to propose a successional history divided into 3 phases: (1) an initiation phase while the larvacean is present; (2) after abandonment, a microcosm phase with an associated microbial community; and (3) after utilization of the outer house, a remnant phase. Absolute abundances of bacteria and protozoans on Phase 2 aggregates were similar to those of detrital microbial communities associated with decaying macroalgae and estuarine macrophytes. The ratio of the biomass of bacterial predators/bacteria was significantly greater on Phase 2 aggregates than for the microbial community in the surrounding water during active upwelling, but values for the ratio from both systems were similar during the postupwelling stratified period. Thus, aggregates sometimes represent small-scale patches of detrital or late-successional microbial communites suspended in a water column undergoing early successional events.
\end{abstract}

\section{INTRODUCTION}

In pelagic ecosystems, a significant proportion of primary production is known to pass through microbial heterotrophs (Fuhrman \& Azam 1980, Williams 1981, Linley et al. 1983). In the euphotic zone, the most studied heterotrophic systems are those of the freeliving microbes. Dissolved organic material originating from phytoplankton is utilized by bacteria that are subsequently grazed by a complex array of phagotrophic flagellates and ciliates that form the microbial food web. This microbial heterotrophic community converts detrital material into living biomass and regenerates nutrients for further algal production (Harrison 1978, Azam et al. 1983). The extent of development of this 'microbial loop' (Azam et al. 1983) in the plankton varies in relation to the succession of phytoplankton blooms and can range from near absent

- Present address: Harbor Branch Oceanographic Institution, 5600 Old Dixie Highway, Fort Pierce, Florida 33450, USA to being the dominant process among microbial plankters (Sorokin 1977).

Benthic and macrophyte detrital systems also incorporate a community of microbial heterotrophs with a food chain similar to that of the microbial community in the pelagic zone (Fenchel \& Harrison 1976, Fenchel \& Jørgensen 1977, Linley et al. 1981). However, these micro-organisms are more concentrated than in the pelagic zone and the community is established on or near a solid subtratum. The detrital resources for such substrata-associated populations are macroalgae, seagrasses (Mann 1976, Linley et al. 1981) and animal debris (Rodina 1963), including fecal matter (Johannes \& Satomi 1966, Honjo \& Roman 1978, Jacobsen \& Azam 1984).

Marine snow aggregates are microhabitats in the pelagic zone that support populations possessing some combined features of both the pelagic and benthic systems. These aggregates contain high concentrations of autotrophic and heterotrophic microbes derived from the pelagic, free-living populations, but are 
assembled together in a matrix of flocculent detrital material (Silver et al. 1978). Sources of nutrition for the heterotrophic microbes are both exudates from autotrophs and mucous detritus, sometimes of animal origin. While these microcosms remain suspended, they co-exist spatially and temporally with the free-living microbes.

This paper reports a study of specific marine snow aggregates - those derived from abandoned larvacean houses (Alldredge 1972, 1976, 1977). From differences measured in the aggregates and their associated microbial communities, we propose a life history divided into 3 well-defined successional phases. These phases are described and the microbial communities associated with the aggregates are compared to substrataassociated communities and to surrounding water communities under different hydrographic regimes.

\section{METHODS}

Field collections. Aggregates and samples of unfiltered sea water (SW) were collected by SCUBA divers utilizing open-ocean, blue-water techniques described by Hamner (1975). Aggregates were collected individually in cleaned and acid-washed $125 \mathrm{ml}$ screw cap plastic jars and SW samples in 251 collapsible containers. Samples were preserved as soon as they were brought aboard the vessel. The preserving solution for $\mathrm{SW}$ was $25 \%$ glutaraldehyde in sea water $(\mathrm{pH}=7.2)$ that was prefiltered through either a $0.2 \mu \mathrm{m}$ filter for bacteria or through a glass fiber filter for eukaryotes. Subsamples of SW for bacterial counts were placed in scintillation vials and preserved to a final concentration of $2.5 \%$ glutaraldehyde. The remaining water in the collapsible container was preserved to $0.5 \%$ glutaraldehyde for later counts of eukaryotes. Aggregates were pipetted from the sample jars and placed into scintillation vials containing $2.5 \%$ glutaraldehyde in sea water $(\mathrm{pH}=7.2$ ) that had been prefiltered through a $0.2 \mu \mathrm{m}$ filter. Preserved samples were transported and stored refrigerated in the dark.

Microscopy. Samples were counted using a Zeiss Standard 18 microscope equipped with Nomarski optics and an epifluorescence attachment. Zeiss filter set 487701 for the nuclear fluorochrome $4^{\prime} 6$ diamidino-2-phenylindole (DAPI) and set 487709 for the nuclear fluorochrome acridine orange $(\mathrm{AO})$ and chlorophyll a autofluorescence were used. Reticles with etched circles or rectangles of various sizes were chosen to give a mean field count of 20 to 40 organisms (Kirchman et al. 1982) when possible.

Each scintillation vial containing aggregates was poured gently into a small Petri dish for observation with a dissecting microscope. When an aggregate was identified as a larvacean house, the length, width and a third dimension, if possible, were measured with a calibrated ocular micrometer for calculation of the aggregate volume. An aggregate was transferred to a small test tube containing $1 \mathrm{ml}$ of $2 \mu \mathrm{g} \mathrm{ml}^{-1}$ DAPI solution and stained for $15 \mathrm{~min}$. It was then mounted in the DAPI solution under a coverslip sealed with fingernail polish. The now flattened aggregate was again measured with the dissecting microscope; the dimensions were used to calculate the aggregate area. This area was used only to calculate the number of organisms per aggregate and does not represent the surface area of the aggregate matrix.

Microbes on aggregates stained with DAPI were counted using Nomarski optics and epifluorescence either simultaneously or alternately depending on which technique gave the best contrast and image. Ciliates on aggregates were counted by scanning the whole aggregate at $500 \times$. Large nanoplankton were counted by measured transects at $500 \times$. Twenty to 30 fields of small nanoplankton were counted at $500 \times$; if a particular taxon or other category was low in number, then it was counted by transect. The phagotrophic microflagellates were identified by size, shape and morphological characteristics, e.g. the transverse flagellum of Bodo and the proboscis of Rhynchomonas (Fenchel 1982b). Thirty fields of bacteria were counted at $1187 \times$ magnification using epifluorescence only. All organisms on aggregates showed contagious distributions. If transects were used or fewer than 30 fields were counted, the data were transformed $\left(\log _{10}\right)$ for calculation of confidence limits (Elliot 1971).

Bacterial numbers in SW were estimated by the epifluorescence acridine orange direct count (AODC) technique (Hobbie et al. 1977). The AO was used at a final concentration of $0.01 \%$. Bacteria from $2 \mathrm{ml}$ of SW were counted by fields at $1187 \times$ magnification. Thirty fields on each of 2 replicate filters were counted for each sample date. Eukaryotes other than ciliates from SW samples were counted similarly using the AODC technique. Forty $\mathrm{ml}$ of preserved SW stained to a final concentration of $0.001 \%$ AO were filtered onto Sartorius $0.45 \mu \mathrm{m}$ black filters at $<10 \mathrm{~cm} \mathrm{Hg}$ and the eukaryotes counted. The organisms were counted by taxon when obvious, e.g. dinoflagellates, or placed into categories according to size and trophic position.

The category 'total eukaryotes $<5 \mu \mathrm{m}$ equivalent spherical diameter (ESD)' was treated again in order to view the heterotrophic microflagellates in the same way they were viewed on the aggregates. One 1 of preserved SW sample was filtered onto a $47 \mathrm{~mm}$ dia. $1.0 \mu \mathrm{m}$ Nuclepore filter at $<10 \mathrm{~cm} \mathrm{Hg}$ and the contents flushed into a small vial using $2 \%$ glutaraldehyde in sea water in a syringe with a small bore needle. The suspension was allowed to settle for $72 \mathrm{~h}$, then the 
supernatant in the settling tubes was removed to a volume of $0.3 \mathrm{ml}$ with a pipet and checked for the absence of organisms by staining and mounting on a filter. The settled sample was stirred and $10 \mu \mathrm{l}$ was removed using an Eppendorf pipet and mounted on a microscope slide under a $25 \mathrm{~mm}$ square cover slip (sealed with fingernail polish) for observation with Nomarski optics. The category 'total eukaryotes $<5 \mu \mathrm{m}$ ESD' in these preparations were counted and the obligate phagotrophic microflagellates were identified in the same way they were on the aggregates. The numbers of heterotrophs were subtracted from the total eukaryotes to obtain a ratio of autotrophs/heterotrophs. This ratio was applied to the counts of total eukaryotes $<5 \mu \mathrm{m}$ ESD obtained from the Sartorius black filters to calculate the absolute abundances of autotrophic and heterotrophic microflagellates in the SW samples.

Ciliates from SW were concentrated and counted using DAPI stain in a procedure modified from that of Porter \& Feig (1980). A $250 \mathrm{ml}$ sample of $\mathrm{SW}$ was filtered by gravity flow onto a $25 \mathrm{~mm}$ diameter disc of $10 \mu \mathrm{m}$ mesh Nitex screen. The screen was flushed and backwashed using $2.5 \%$ glutaraldehyde in sea water. The resulting concentrated solution of organisms was filtered to near completion onto a Sartorius $25 \mathrm{~mm}$ diameter, $0.45 \mu \mathrm{m}$ black filter at $<10 \mathrm{~cm} \mathrm{Hg}$. The filter was then flooded with a sea water solution of $2 \mu \mathrm{g} \mathrm{ml}^{-1}$ DAPI, allowed to stand for $5 \mathrm{~min}$, after which filtration was completed and the filter mounted for observation. Ciliates were readily visible using this technique; they were counted at $500 \times$ magnification by transects. This procedure may not have sampled all of the small aloricate ciliates in the SW samples (Sherr et al. 1986). However, abundances as high as 18 ciliates $\mathrm{ml}^{-1}$ were counted in samples from these neritic waters.

Calculations. The number of organisms on each aggregate was calculated by multiplying the mean field count by the ratio, aggregate area/field area. This value was then normalized to a concentration by multiplying it by the number of aggregates per ml. These values were compared to sea water concentrations by calculating an enrichment factor (EF) for each category of organism: $\mathrm{EF}=$ (number of organisms $\mathrm{ml}^{-1}$ on an aggregate)/(number of organism $\mathrm{ml}^{-1}$ in sea water).

Linear dimensions of organisms were made with a calibrated ocular micrometer using Nomarski optics. Volumes of organisms were calculated assuming a spherical or ellipsoid shape except large loricate ciliates, which were considered to be cones. Carbon content per cell for autotrophs and heterotrophic flagellates was estimated using the non-diatom formula of Strathmann (1967), i.e. $\log _{10}$ Carbon (pg) = $0.866 \log _{10}$ Volume $\left(\mu \mathrm{m}^{3}\right)-0.460$. Ciliate carbon (pg) was calculated as $0.08 \times$ volume $\left(\mu \mathrm{m}^{3}\right)$ (Beers \& Stewart 1970). The carbon content of bacteria was calculated using the conversion factor of $0.121 \mathrm{pg} \mathrm{C}$ $\mu \mathrm{m}^{-3}$ cell volume (Watson et al. 1977) rather than the recently suggested factor of $0.22 \mathrm{pg} \mathrm{C} \mu \mathrm{m}^{-3}$ (Bratbak \& Dundas 1984) in order to compare our biomass data with previously published values (see Table 4).

Statistics. Non-parametric statistical tests of the EFs from individual aggregates were used to indicate patterns of enrichment of microbial populations that occupied different trophic positions. A Kruskal-Wallis 1 -way analysis of the ranks of EFs of all categories from individual aggregates from each sample date was performed to determine if any one category was significantly more enriched than any other. When the Kruskal-Wallis analysis was significant for a set of aggregates, Dunn's pairwise comparison analysis with an experimentwise error rate of 0.10 (Hollander \& Wolfe 1973) was performed on the same ranks to determine which categories were more significantly enriched than others.

\section{RESULTS}

\section{Hydrography}

The dates, physical parameters and hydrographic regimes at each sample site are listed in Table 1 . The collection site $\left(36^{\circ} 52^{\prime} \mathrm{N}, 122^{\circ} 02^{\prime} \mathrm{W}\right)$ was $8 \mathrm{~km}$ from shore in $75 \mathrm{~m}$ of water. Increases in the salinity at $10 \mathrm{~m}$ in the spring signal upwelling in Monterey Bay (Bolin

Table 1. Dates of samples and hydrographic conditions under which samples were taken. The depth is the nominal depth of the divers

\begin{tabular}{|c|c|c|c|c|}
\hline $\begin{array}{l}\text { Date } \\
1981\end{array}$ & $\begin{array}{l}\text { Depth } \\
\text { (m) }\end{array}$ & $\begin{array}{l}\text { Temp. } \\
\left({ }^{\circ} \mathrm{C}\right)\end{array}$ & $\begin{array}{c}\text { Salinity } \\
(\% \circ)\end{array}$ & $\begin{array}{l}\text { Hydrographic } \\
\text { conditions }\end{array}$ \\
\hline $24 \mathrm{Apr}$ & 10 & 12.8 & 33.7 & Upwelling \\
\hline 1 May & 10 & 13.0 & 33.9 & Upwelling \\
\hline $8 \mathrm{May}$ & 10 & 12.8 & 33.5 & Upwelling \\
\hline 19 Jun & 10 & 12.8 & 34.0 & $\begin{array}{l}\text { Upwelling } \\
\text { (deep source) }\end{array}$ \\
\hline $14 \mathrm{Jul}$ & 10 & 15.0 & 33.8 & Post-upwelling \\
\hline
\end{tabular}

\& Abbott 1963, Garrison 1979). Lower salinity water (33.2ppt at $10 \mathrm{~m}$ ) measured on 12 February 1981 and again on 24 March 1981 followed by higher salinity water ( 33.7 ppt at $10 \mathrm{~m}$ ) on 24 April 1981 indicated that upwelling began sometime in April with source water from a shallow depth (approximately $50 \mathrm{~m}$ ). Continued high salinities and low temperatures at $10 \mathrm{~m}$ (Table 1) denoted that upwelling continued with varying intensity through the June sampling. The June water had the highest salinity $(34.0 \mathrm{ppt}$ at $10 \mathrm{~m})$ suggesting that the source was deeper than in April (approximately 
$100 \mathrm{~m}$ ). The July samples were taken during the postupwelling season when the water column was stratified with a $20 \mathrm{~m}$ upper mixed layer.

\section{Sea water microbes: abundance and diversity}

The taxonomic composition, diversity and abundances of microorganisms in unfiltered sea water samples (SW) varied with the date (Table 1) of sample collection. In April, the dominant ciliates were choreotrichs including Laboea and Strombidium. Furthermore, this ciliate assemblage in the SW samples was the most abundant (18 ciliates $\mathrm{ml}^{-1}$ ) and the most diverse (10 taxa) of all sample dates. The maximum abundance of bacteria in SW $\left(4.25 \times 10^{6} \mathrm{ml}^{-1}\right)$ also occurred in April. At the same time, a 12 to $15 \mu \mathrm{m}$ ESD (biovolume 900 to $1800 \mathrm{\mu m}^{3}$ ) flagellated chlorophyte, that sporadically blooms in Monterey Bay (Garrison 1979), and a similar size naked dinoflagellate were abundant $\left(1000\right.$ cells ml $\mathrm{m}^{-1}$ and 300 cells $\mathrm{ml}^{-1}$, respectively). In both May SW samples, the microbial community was similar in taxonomic composition to that in April except that in May the abundances of ciliates and bacteria had decreased ( 2 ciliates $\mathrm{ml}^{-1}$ and $1.2 \times 10^{6}$ bacteria $\mathrm{ml}^{-1}$ ). In June, the ciliate and dinoflagellate populations were sparse in SW samples $(0.4$ ciliate $\mathrm{ml}^{-1}$ and 2 dinoflagellates $\mathrm{ml}^{-1}$ ) and the chlorophyte was absent. Thus, most autotrophs were small $1<5 \mu \mathrm{m}$ ESD, biovolume $<65 \mu^{3}$ ). Choanoflagellates were a conspicuous component of the heterotrophic flagellate population in June. In July, the most numerous ciliate was Uronema sp., and tintinnids were present. The assemblage of heterotrophic flagellates in the SW samples in July was the most diverse ( 7 taxa) and the individuals were the most abundant $\left(1.8 \times 10^{3}\right.$ cells $\mathrm{ml}^{-1}$ ) among the sample dates. The heterotrophic flagellates included at least 2 genera of kinetoplastida (Bodo and Rhynchomonas), a large cryptomonad, choanoflagellates and an amoeboflagellate species. Most autotrophs in July were small (biovolume $<65$ $\mu \mathrm{m}^{3}$ ), although the naked dinoflagellates seen in April and May had reappeard.

\section{Aggregate microbes: abundance and enrichment}

The absolute abundances of microbes in categories on aggregates and their enrichment factors (EF) are listed in Table 2. All of the aggregates studied were abandoned larvacean houses. The EF values were calculated using counts from unfiltered sea water (SW) and therefore are minimum values; unfiltered sea water may have contained microbes from houses disrupted during handling and filtration. However, calculations of the number of houses $I^{-1}$ and the number of microbes house $e^{-1}$ suggest a maximum of $15 \%$ of the SW microbes could have been contributed by organisms on houses. All microbes were more concentrated on houses than in unfiltered sea water $(E F>1)$ with $E F$ values ranging from 80 to 2100 depending on category and date of sampling (Table 2). All taxa that were associated with houses were also seen in the SW samples collected at the same time and location.

\section{Aggregates: composition and community structure}

Although all of the aggregates studied were abandoned larvacean houses, those sampled in April were different in size, composition of the matrix, and structure of the microbial community from those sampled at

Table 2. Mean number of organisms $\mathrm{ml}^{-1}$ of aggregate and enrichment factors $\left(\mathrm{EF}\right.$ ); $\mathrm{EF}=$ (number $\mathrm{m} \mathrm{l}^{-1}$ aggregate) $/(\mathrm{number}$ $\mathrm{ml}^{-1}$ in unfiltered water). Numbers in parentheses below each mean value are $1 \mathrm{SE}$

\begin{tabular}{|c|c|c|c|c|c|c|c|c|c|c|c|}
\hline \multirow[t]{2}{*}{$\begin{array}{l}\text { Date } \\
1981\end{array}$} & \multirow[t]{2}{*}{$\begin{array}{l}\text { Aggregate } \\
\text { volume } \\
(u l)\end{array}$} & $\times 10$ & $\begin{array}{l}\text { tes } \\
\mathrm{ml}^{-1}\end{array}$ & \multicolumn{2}{|c|}{$\begin{array}{c}\text { Heterotrophic } \\
\text { flagellates } \\
\times 10^{5} \mathrm{ml}^{-1}\end{array}$} & \multicolumn{2}{|c|}{$\begin{array}{l}>5 \mu \mathrm{m} \text { ESD } \\
\text { autotrophs } \\
\times 10^{4} \mathrm{ml}^{-1}\end{array}$} & \multicolumn{2}{|c|}{$\begin{array}{l}<5 \mu \mathrm{m} \text { ESD } \\
\text { autotrophs } \\
\times 10^{6} \mathrm{ml}^{-1}\end{array}$} & \multicolumn{2}{|c|}{$\begin{array}{l}\text { Bacteria } \\
\times 10^{8} \mathrm{ml}^{-1}\end{array}$} \\
\hline & & $\overline{\mathrm{X}}$ & $E F$ & $\bar{X}$ & EF & $\bar{X}$ & $E F$ & $\bar{X}$ & $\mathrm{EF}$ & $\bar{x}$ & $E F$ \\
\hline $\begin{array}{r}\text { 24. Apr } \\
\mathrm{n}=6\end{array}$ & $\begin{array}{l}1.2 \\
(0.12)\end{array}$ & $\begin{array}{c}5.75 \\
(1.84)\end{array}$ & 316 & $\begin{array}{c}1.49 \\
(0.62)\end{array}$ & 260 & $\begin{array}{l}25.5 \\
(10.30)\end{array}$ & 201 & $\begin{array}{c}0.67 \\
(0.19)\end{array}$ & 158 & $\begin{array}{c}3.52 \\
(0.59)\end{array}$ & 83 \\
\hline $\begin{array}{l}1 \text { May } \\
\mathrm{n}=3\end{array}$ & $\begin{array}{l}12.5 \\
(0.47)\end{array}$ & $\begin{array}{c}0.50 \\
(0.48)\end{array}$ & 110 & $\begin{array}{c}2.78 \\
(0.50)\end{array}$ & 712 & $\begin{array}{l}23.5 \\
(5.29)\end{array}$ & 88 & $\begin{array}{c}1.52 \\
(0.49)\end{array}$ & 131 & $\begin{array}{c}2.86 \\
(0.59)\end{array}$ & 246 \\
\hline $\begin{array}{l}8 \text { May } \\
n=6\end{array}$ & $\begin{array}{l}19.4 \\
(5.63)\end{array}$ & $\begin{array}{c}0.98 \\
(0.30)\end{array}$ & 518 & $\begin{array}{c}2.84 \\
(0.94)\end{array}$ & 504 & $\begin{array}{l}20.6 \\
(7.06)\end{array}$ & 75 & $\begin{array}{c}1.15 \\
(0.45)\end{array}$ & 177 & $\begin{array}{c}3.43 \\
(1.59)\end{array}$ & 298 \\
\hline $\begin{array}{r}19 \text { Jun } \\
n=4\end{array}$ & $\begin{array}{l}8.3 \\
(2.44)\end{array}$ & $\begin{array}{c}1.00 \\
(0.27)\end{array}$ & 2131 & $\begin{array}{c}3.41 \\
(0.53)\end{array}$ & 987 & $\begin{array}{c}0.22 \\
(0.05)\end{array}$ & 1118 & $\begin{array}{c}1.16 \\
(0.16)\end{array}$ & 140 & $\begin{array}{c}2.21 \\
(0.27)\end{array}$ & 206 \\
\hline $\begin{array}{l}14 \mathrm{Jul} \\
\mathrm{n}=7\end{array}$ & $\begin{array}{l}15.3 \\
(4.45)\end{array}$ & $\begin{array}{c}4.84 \\
(2.05)\end{array}$ & 496 & $\begin{array}{c}1.91 \\
(0.36)\end{array}$ & 107 & $\begin{array}{c}0.41 \\
(0.21)\end{array}$ & 318 & $\begin{array}{c}0.36 \\
(0.08)\end{array}$ & 104 & $\begin{array}{c}1.51 \\
(0.22)\end{array}$ & 151 \\
\hline
\end{tabular}


other times. In April, microscopic observation revealed that the outer part of the house including the outer house membrane (Alldredge 1977) was absent. The aggregates were made of the fibrils of the internal and incurrent filters. The mean volume of the aggregates sampled in April (Table 2) was significantly smaller than the mean volume of all other aggregates from other sampling periods (Mann-Whitney U test, $\mathrm{P}<$ 0.001 ). Finally, a Kruskal-Wallis test (Table 3) indi-

Table 3. Results of statistical tests for differences among enrichment factors (EF) of different trophic categories. Five trophic categories were used for the Kruskal-Wallis (K-W test) and the Dunn's pairwise comparison: $\mathrm{C}=$ ciliates; $\mathrm{HF}=$ heterotrophic flagellates; $\mathrm{LA}=$ large autotrophs (i.e. $>5 \mu \mathrm{m}$ ESD); $\mathrm{SA}=$ small autotrophs $(<5 \mu \mathrm{m}$ ESD $) ; \mathrm{B}=$ bacteria Entries are ranks of EFs for replicate aggregates from each sampling date. K-W tests for the existence of difference among any pair of trophic categories and Dunn's pairwise comparison identifies which of the trophic categories caused the significant differences

\begin{tabular}{|cccc|}
\hline $\begin{array}{c}\text { Sample } \\
\text { dates } \\
1981\end{array}$ & $\begin{array}{c}\text { Aggregate } \\
\text { phase }\end{array}$ & $\begin{array}{c}\text { K-W test } \\
\text { result } \\
(\mathrm{P})\end{array}$ & $\begin{array}{c}\text { Dunn test } \\
\text { result }\end{array}$ \\
\hline 24 Apr & 3 & $>0.05$ & $\begin{array}{l}- \\
1 \text { May }\end{array}$ \\
& 2 & $<0.05$ & $\begin{array}{l}\mathrm{HF}>\mathrm{C} \\
\mathrm{HF}>\mathrm{LA}\end{array}$ \\
8 May & 2 & $<0.25$ & $\begin{array}{l}\mathrm{C}>\mathrm{LA} \\
\mathrm{HF}>\mathrm{LA}\end{array}$ \\
19 Jun & 2 & $<0.01$ & $\begin{array}{l}\mathrm{C}>\mathrm{SA} \\
\mathrm{C}>\mathrm{B}\end{array}$ \\
& & & $\begin{array}{l}\mathrm{HF}>\mathrm{SA} \\
\mathrm{C}>\mathrm{HF}\end{array}$ \\
14 Jul & 2 & $<>\mathrm{SA}$ \\
& & & \\
\hline
\end{tabular}

cated that no category of microbes had accumulated on the aggregates to a significantly greater extent than any other.

The aggregates sampled in May, June and July were whole larvacean houses with the internal filters surrounded by outer house mucous material and the outer house membrane. The larger mean displacement volumes are given in Table 2. A Kruskal-Wallis test followed by a Dunn's pairwise comparison test (Table 3) on aggregates from each date of sampling during May, June and July indicated that phagotrophic protozoans (the categories of heterotrophic flagellates or ciliates) had accumulated on the aggregates to a greater extent than other categories of microbes.

\section{Aggregate and surrounding water communities compared}

The ratio ( $\%$, based on carbon) of bacterial predators/bacteria and the ratio (\%, based on carbon) of heterotrophic flagellates/bacteria (Table 4) were used as indexes of the degree of development of a bacterial based food chain both for aggregates and for freeliving populations in the SW samples. Both ratios were calculated to enable comparison of the data from this study with other published work (see Table 4). Values of the index bacterial predators/bacteria for aggregates that were whole houses (aggregates sampled during May and June) ranged from 19 to $46 \%$. During that time, the values of that index for the community in SW samples were each significantly lower ( 7 to $10 \%)$ than the comparable values from aggregates (see

Table 4. Indexes of the degree of development of the heterotrophic food chains in aggregates (Agg) and water (SW). Ratios are of mean standing stock of carbon. Bacterial consumers include heterotrophic flagellates and the ciliate Uronema only; heterotrophs include all ciliates, heterotrophic flagellates and bacteria

\begin{tabular}{|c|c|c|c|c|c|c|c|}
\hline \multirow[t]{2}{*}{$\begin{array}{l}\text { Date or } \\
\text { source }\end{array}$} & \multirow[t]{2}{*}{$\begin{array}{l}\text { Water } \\
\text { column } \\
\text { state }\end{array}$} & \multicolumn{2}{|c|}{$\begin{array}{c}\text { Bacterial } \\
\text { consumers/ } \\
\text { bacteria* }(\%)\end{array}$} & \multicolumn{2}{|c|}{$\begin{array}{c}\text { Heterotrophic } \\
\text { flagellates } \\
\text { bacteria }(\%)\end{array}$} & \multicolumn{2}{|c|}{$\begin{array}{c}\text { Heterotrophs } \\
\text { autotrophs } \\
(\%)\end{array}$} \\
\hline & & Agg & SW & $\mathrm{Agg}$ & $\mathrm{SW}$ & Agg & SW \\
\hline 24 Apr 81 & Upwelling & - & - & - & - & 50 & 130 \\
\hline 1 May 81 & Upwelling & 24.5 & 7.1 & 24.5 & 7.1 & 100 & 30 \\
\hline 8 May 81 & Upwelling & 19.2 & 10.0 & 16.7 & 10.0 & 100 & 20 \\
\hline 19 Jun 81 & Upwelling & 45.7 & 8.2 & 45.7 & 8.2 & 200 & 100 \\
\hline 14 Jul 81 & Stratified & 45.3 & 42.0 & 38.4 & 40.0 & 250 & 250 \\
\hline Detrital systems ${ }^{b}$ & & 100 & - & & & & \\
\hline Linley et al. $1983^{c}$ & Mixed & & & & 6.3 & & \\
\hline Linley et al. $1983^{\circ}$ & Frontal & & & & 9.3 & & \\
\hline Linley et al. $1983^{\circ}$ & Stratified & & & & 78.2 & & \\
\hline Sorokin $1977^{d}$ & Stratified & & & & 80 & & \\
\hline \multicolumn{8}{|c|}{$\begin{array}{l}\text { d Values plotted in Fig. } 1 \\
{ }^{b} \text { Accumulations of small detrital particles (Fenchel \& Harrison 1976) } \\
\text { cFrom Linley et al. (1983), their Table 5, } 2 \text { to } 12 \mathrm{~m} \\
{ }^{d} \text { From Sorokin (1977), his Fig. 5, } 30 \mathrm{~m}\end{array}$} \\
\hline
\end{tabular}


Fig. 1). On the other hand, the values of the indexes from both aggregates and SW were similar for the July sample. Differences between the communities on whole and disintegrated houses and in SW communities at different times were represented by the ratio (\%, based on carbon) of heterotrophs/autotrophs (Table 4). The aggregates sampled in April (those with only the internal filter fibers remaining) harbored communities with high standing stocks of autotrophs compared to the heterotrophic component on those aggregates.

\section{DISCUSSION}

\section{Successional sequence of aggregates}

The differences in the size and composition of aggregates, and the structure of the microbial community found between aggregates sampled in April and those sampled in May, June and July (see 'Results') suggested differences in the nature of those sets of aggregates. Since all aggregates were abandoned larvacean houses, the differences were interpreted as representing phases in a process of maturation. The successional phases of a larvacean house from initiation by the animal to a remnant aggregate were designated as follows: (1) an initiation phase; (2) a microcosm phase; and (3) a smaller remnant phase.

The initiation phase (Phase 1) begins with the secre-

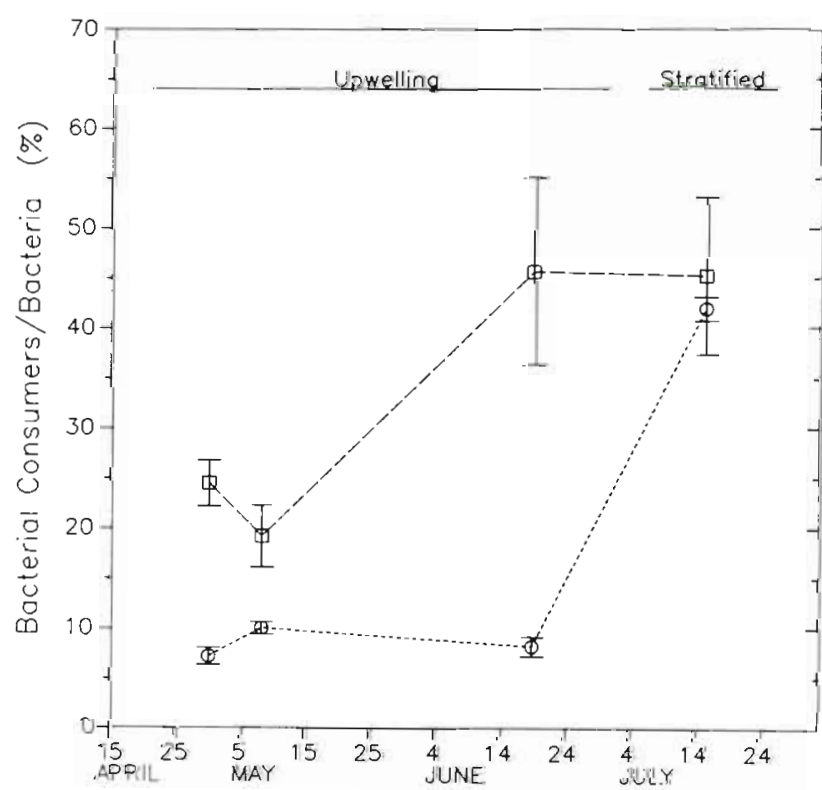

Fig. 1. Index of development of a heterotrophic food chain on aggregates and in the surrounding water during upwelling and post-upwelling stratified periods. The index is the ratio, bacterial consumers/bacteria in terms of the standing stocks of carbon (\%, from Table 4). (口): aggregates; (O): unfiltered sea water. Error bars are $\pm 1 \mathrm{SE}$ tion and expansion of the external house by the larvacean and ends when the house is clogged with particles and abandoned by the animal (Alldredge 1976). During this 4 to $6 \mathrm{~h}$ period (Alldredge 1976, Paffenhofer 1973), the animal feeds on particles brought into the house with water currents created by the sinusoidal beating of its tail. Many of the organisms entering the house do not become food for the animal, but rather stick to the detrital matrix of filters and outer house material and serve as the inocula for the microbial community of Phase 2 .

Phase 2 is that period of time immediately after abandonment when a complete house functions as a microbial microcosm. It proceeds until the mucous outer house has been utilized, presumably by heterotrophic microbes. We estimate that Phase 2 lasts 4 to $6 \mathrm{~d}$. In preliminary experiments in this laboratory (unpubl. data), microbes, in the absence of metazoans, took about $6 \mathrm{~d}$ to degrade the outer house. A similar time (approximately $4 \mathrm{~d}$ ) has been reported by Pomeroy \& Deibel (1980) for microbial degradation of the flocculent feces of pelagic tunicates. The aggregates sampled during May, June and July were abandoned whole houses in the Phase 2 stage of development.

The autotrophic component of the microbial community on Phase 2 aggregates was different than that reported for other types of marine snow. Phase 2 aggregates had absolute abundances of nano-autotrophs ( 2 to $20 \mu \mathrm{m}$ ESD, biovolume 4.2 to $4200 \mu \mathrm{m}^{3}$ ) ranging from 0.4 to $1.7 \times 10^{6}$ cells $\mathrm{ml}^{-1}$ of aggregate (see Table 2). Such abundances are 1 to 2 orders of magnitude greater than occurred on marine snow derived from pteropods and ctenophores in surface waters of the Atlantic (Caron et al. 1982). Furthermore, diatoms, which were rare on Phase 2 aggregates, were present in high numbers $\left(1.5 \times 10^{5} \mathrm{ml}^{-1}\right)$ on other types of marine snow (Silver et al. 1978). The high concentrations of small autotrophs on Phase 2 aggregates may have been the result of active inoculation during Phase 1 as well as growth by the inoculated population. Diatoms were likely excluded by the incurrent filters (Alldredge 1977).

Phase 2 aggregates also had high abundances of heterotrophic bacteria and phagotrophic protozoans (Table 2). These high abundances of heterotrophic microbes associated with the detrital material of the abandoned houses are comparable to other detrital systems (Table 5). The Phase 2 aggregates from this study had concentrations of heterotrophic microbes within or above the range reported for those associated with solid substrata.

The protozoans were shown by statistical analysis to have had significantly greater EF values than other trophic classes of microbes on Phase 2 aggregates 
Table 5. Comparisons of the concentrations of microbes characteristically found associated with detritus

\begin{tabular}{|c|c|c|c|c|c|}
\hline System & Method & Bacteria $\mathrm{cm}^{-2}$ & $\begin{array}{c}\text { Bacteria } \mathrm{g}^{-1} \\
\text { dry wt detritus }\end{array}$ & $\begin{array}{l}\text { Het. flag. g } \\
\text { dry wt detritus }\end{array}$ & $\begin{array}{l}\text { Ciliates } \mathrm{g}^{-1} \\
\text { dry wt detritus }\end{array}$ \\
\hline Aggregates, this study & Fluor ${ }^{a}$ & $1.3 \times 10^{7}$ & $10^{11}$ & $10^{8}$ & $10^{6}$ \\
\hline Laminaria frond tips ${ }^{\mathrm{b}}$ & Plate counts & $1.0 \times 10^{5}$ & - & - & - \\
\hline Detritus particles ${ }^{c}$ & Fluor & $10^{13}-10^{7}$ & $10^{9}-10^{10}$ & $5 \times 10^{\prime}-5 \times 10^{8}$ & $10^{4}-10^{5}$ \\
\hline Detritus $^{d}$ & Fluor & - & $7.5 \times 10^{10}$ & - & - \\
\hline Deep-sea detritus to $2000 \mathrm{~m}^{\prime \prime}$ & Light microscopy & - & - & - & $10^{6}$ \\
\hline \multicolumn{6}{|c|}{$\begin{array}{l}\text { a Fluorescence microscopy with nuclear fluorochromes } \\
{ }^{b} \text { Laycock } 1974 \\
\text { 'Data for marine benthic detrital particles originating from macrophytes (Fenchel 1977) } \\
\text { d Date for lake benthic detritus (Rodina 1963) } \\
\text { e Ciliate numbers from sinking organic particles collected in sediment traps (Silver et al. }\end{array}$} \\
\hline
\end{tabular}

(Table 3). This implies that protozoan populations were increasing relatively more rapidly than other organisms. This apparent rapid accumulation of protozoans was presumably due to some combination of the following 3 factors: the inoculation process, an abundant food supply, and the absence of metazoan grazers. No metazoans were seen inside Phase 2 houses that could have selectively grazed the populations of protozoans. Crustacean browsers have been seen on the outside of a high percentage of houses in the field (Alldredge 1972). However these browsers scrape the mucus and pull it and all attached organisms to the mouth parts, a feeding method that is likely nonselective.

The populations of producers (autotrophs and bacteria) were presumably increasing fast enough to support the ciliates and heterotrophic flagellates as well as to maintain concentrated standing stocks of their own. Autotrophs are known to be active photosynthesizers on aggregates (Alldredge \& Cox 1982, Knauer et al. 1982). Several organic substrates were available for utilization by the bacteria: the original mucous matrix, dissolved organic matter released from resident autotrophs and lysing cells, larvacean fecal pellets deposited in the houses and particulate detritus caught in the meshes.

The result of the simultaneous inoculation and concentration of all trophic members of the microbial complex from the balanced community already existing in the water outside the house during Phase 1 is to have organisms already coupled in predator-prey interrelations (bacteria and heterotrophic flagellates) continue interacting, but with greater intensity. This is in contrast to laboratory studies of the microbial degradation of detrital material from macrophytes that show successional colonization of microbes beginning with bacteria followed by heterotrophic flagellates and then ciliates (Fenchel \& Jørgensen 1977, Linley et al. 1981, Linley \& Newell 1984). Incubations of unaltered detrital fecal material from the pelagic zone also result in sequential colonization (Pomeroy \& Deibel 1980, Pomeroy et al. 1984). With simultaneous inoculation, however, heterotrophic flagellates and ciliates may have found enough food to have begun grazing and reached exponential growth rates before or immediately after the houses became abandoned. Metabolic or respiration rates of heterotrophic flagellates can increase rapidly when they are moved from low to high bacterial food concentrations (Fenchel 1982a). Immediate and continued grazing likely maintained populations of fast growing bacterial strains (Fenchel \& Harrison 1976, Fenchel 1977), but they were consumed by the phagotrophic protozoans. The simultaneous inoculation of all trophic levels of microbes may have contributed to the significantly higher EF values of phagotrophs on all Phase 2 aggregates.

Phase 3 begins after the outer house has been disrupted leaving the filamentous filter material as the center of a smaller remnant aggregate. The aggregates sampled in April were in the Phase 3 stage of maturation. Some areas of the refractory detrital matrix were deplete of bacteria similar to that reported by Pomeroy $\&$ Deibel (1980) for salp feces that were 2 to $4 \mathrm{~d}$ old. In contrast to Phase 2 aggregates, populations of protozoan consumers were not more enriched than other microbes (Kruskal-Wallis test, Table 3 ). This result was likely due to the decrease in bacterial production accompanying the absence of the labile mucous material of the house. Despite the absence of a covering, these aggregates appeared to be a refuge from predation for some microbes. High concentrations of dinoflagellates and motile chlorophytes (the $>5 \mu \mathrm{m}$ ESD autotroph category; Table 2 and 'Results') and large numbers of ciliates were associated with the refractory detrital matrix of the aggregates. The standing stocks of autotrophs were greater than that of heterotrophs (Table 4) indicating that the concentrations of heterotrophic microbes on these aggregates composed primarily of refractory detritus were diminished from their concentrations on Phase 2 aggregates. 


\section{Aggregates and hydrography}

Our samples spanned the seasonal upwelling period in Monterey Bay; both the active upwelling and postupwelling phases that are known to support different planktonic communities (Bolin \& Abbott 1963, Garrison 1979, see 'Results'). Phase 2 and Phase 3 aggregates did not co-occur. Phase 3 aggregates were sampled from surface waters only at the beginning of upwelling on the April sample date. Consumption of the outer house material by heterotrophic microbes must have occurred previously. These refractory aggregates were thought to be at least $6 \mathrm{~d}$ old (see above). Sinking rates of $91 \mathrm{~m} \mathrm{~d}^{-1}$ (Alldredge 1979) and $68 \mathrm{~m} \mathrm{~d}^{-1}$ (Shanks \& Trent 1980) have been estimated for flocculent aggregates. These aggregates may have been kept suspended in the isothermal water column or resuspended from the bottom sediments by the winds that caused the upwelling.

In any case, the aggregates remained ungrazed by metazoans resulting in the nutritive material entering the microbial food web rather than being utilized by macro-zooplankton (Pomeroy 1984, Pomeroy et al. 1984). Phase 2 aggregates were sampled later in the upwelling period and during post-upwelling conditions. All of these aggregates were younger than the Phase 3 aggregates sampled in April. Increased grazing by metazoans as upwelling progressed may have contributed to the youth of the aggregates sampled during upwelling.

All Phase 2 aggregates supported a well-developed microbial food chain signaled by the accumulation of protozoans. In the free-living plankton, however, formation of a well-developed heterotrophic food chain seems to occur only during the late stages of a phytoplankton bloom (Azam et al. 1983, Sorokin 1977). During the later stages of a bloom, resources that induce rapid bacterial growth are provided by exudates from phytoplankton that are physiologically stressed due to nutrient limitation (Joiris et al. 1982, Azam et al. 1983). Seasonally, in temperate waters, nutrient limitation depends on the formation of a thermocline resulting in a stratified water column (Sorokin 1977). Post-bloom conditions in a stratified water column can produce a late successional assemblage of the microplankton, typically, a well-developed microbial loop (Azam et al. 1983) which is comparable to a detrital microbial community associated with Phase 2 aggregates (Table 4).

The degree of the development of a detrital food chain was quantified using the ratio, bacterial predators/bacteria (Table 4). This ratio would be expected to vary considerably in laboratory systems where sterile detrital material is inoculated with a natural source of microbes and the colonization and subsequent succession is documented (e.g. Linley et al.
1981, Stuart et al. 1981, Linley \& Newell 1984). We assumed that the process of simultaneous inoculation and concentration of all trophic levels of microbes, however, would allow the newly formed Phase 2 aggregates to come rapidly to near steady-state conditions. When successional events of microbes on unprocessed detritus were followed, the bacteria were rapidly grazed when protozoans appeared (Pomeroy et al. 1984). We further assumed that there would be no rapid, extreme fluctuations in the index calculated from the SW samples (Fenchel 1982b).

Values for this index were calculated for both aggregates and SW samples, then compared under different hydrographic regimes (Table 4). Low values of the index ( 3 to $10 \%$ ) were calculated for unfiltered water samples taken during upwelling. A mean value of $42 \%$ was found in the mixed layer (upper $20 \mathrm{~m}$ ) for unfiltered water during the post-upwelling period when the water column was stratified. A similar trend of relatively low values in mixed water columns and higher values in a stratified column, using a comparable index (Table 4), has been reported by Linley et al. (1983). A high value of that index was also found by Sorokin (1977) at the thermocline in a stratified water column after a phytoplankton bloom. The results imply that in a mixed water column during upwelling, the heterotrophic food chain is not as well developed as during post-upwelling stratified periods when the detrital food chain is well developed in the free living plankton.

The index of comparison of the communities on Phase 2 aggregates and the surrounding water were significantly different during upwelling but converged and were similar during the post-upwelling stratified period (Fig. 1). The sample showing the greatest divergence was the June sample, determined to have been the time of most intense upwelling. The surface water at that time was in a pre-bloom state. It also had the lowest absolute abundances of ciliates and heterotrophic flagellates among the sample periods as well as a low value of the index. The community present in the surface waters during April and May, consisting of large numbers of dinoflagellates and chlorophytes isee 'Results'), was absent in June, presumably having been advected offshore. The Phase 2 aggregates sampled from this newly upwelled water nevertheless maintained a well-developed heterotrophic food chain. Thus, aggregates sometimes represent small scale patches of late successional microbial communities suspended in a water column undergoing early successional events. The results of aggregate activity, e.g. the utilization of detritus, protozoan grazing of bacteria and regeneration of nutrients, will be proportionately more important during upwelling than during post-upwelling periods. 
Acknowledgements. This research was supported by NSF grant OCE-79-19244, University of California, Santa Cruz. We thank Jim Cowen, Kenneth Coale and Rob Franks for collecting samples by SCUBA. We also thank Marsh Youngbluth, Tom Bailey, Pam Blades-Eckelbarger, Steven Y Newell and anonymous reviewers for helpful comments. Contribution No. 517 Harbor Branch Oceanographic Institution.

\section{LITERATURE CITED}

Alldredge, A. L. (1972). Abandoned larvacean houses: A unique food source in the pelagic environment. Science 177: $885-887$

Alldredge, A. L. (1976). Discarded appendicularian houses as sources of food, surface habitats, and particulate organic matter in planktonic environments. Limnol. Oceanogr. 21: $14-23$

Alldredge, A. L. (1977). House morphology and mechanisms of feeding in the oikopleuridae (Tunicata, Appendicularia). J. Zool., Lond. 181: 175-188

Alldredge, A. L. (1979). The chemical composition of macroscopic aggregates in two neritic seas. Limnol. Oceanogr $24: 855-866$

Alldredge, A. L., Cox, J. L. (1982). Primary productivity and chemical composition of marine snow in surface waters of the Southern California Bight. J. mar. Res. 40: 517-527

Azam, F., Fenchel, T., Field, J. G., Gray, J. S., Meyer-Reil, L. A., Thingstad, F. (1983). The ecological role of watercolumn microbes in the sea. Mar. Ecol. Prog. Ser. 10 257-263

Beers, J. R., Stewart, G. L. (1970). Numerical abundance and estimated biomass of microzooplankton. In: Strickland, J. D. H. (ed.) The ecology of the plankton off La Jolla California in the period April through September, 1967 Bull. Scripps Inst. Oceanogr. 17: 67-87

Bolin, R. L., Abbott, D. P. (1963). Studies of the marine climate and phytoplankton of the central coastal area of California, 1954-1960. Calif. Coop. Oceanic Fish. Invest. Rep. No. 9: 23-45

Bratbak, G., Dundas, I. (1984). Bacterial dry matter content and biomass estimations. Appl. environ. Microbiol. 48 755-757

Caron, D. A., Davis, P. G., Madin, L. P., Sieburth, J. McN. (1982). Heterotrophic bacteria and bacterivorous Protozoa in oceanic macroaggregates. Science 218: 795-797

Elliott, J. M. (1971). Some methods for the statistical analysis of samples of benthic invertebrates. Freshwater Biological Association, Ambleside, UK, Scientific Publication No. 25

Fenchel, T. (1977). The significance of bactivorous Protozoa in the microbial community of detrital particles. In: Cairns, J. Jr. (ed.) Aquatic microbial communities. Garland Publishing, New York \& London, p. 531-544

Fenchel, T. (1982a). Ecology of heterotrophic microflagellates. III. Adaptations to heterogeneous environments. Mar. Ecol. Prog. Ser. 9: 25-33

Fenchel, T. (1982b). Ecology of heterotrophic microflagellates. IV. Quantitative occurrence and importance as bacterial consumers. Mar. Ecol. Prog. Ser. 9: 35-42

Fenchel, T. M., Jørgensen, B. B. (1977). Detritus food chains of aquatic ecosystems: The role of bacteria. Adv. microb. Ecol. 1: 1-58

Fenchel, T., Harrison, P. (1976). The significance of bacterial grazing and mineral cycling for the decomposition of particulate detritus. In: Anderson, J. M., Macfadyen, A. (ed.) The role of terrestrial and aquatic organisms in decomposition processes. Blackwell Sci. Pub., Oxford, p. 285-299

Fuhrman, J. A., Azam, F. (1980). Bacterioplankton secondary production estimates for coastal waters of British Columbia, Antarctica, and California. Appl. environ. Microbiol. 39: 1085-1095

Garrison, D. L. (1979). Monterey Bay phytoplankton I. Seasonal cycles of phytoplankton assemblages. J. Plankton Res. 1: 241-265

Hamner, W. M. (1975). Underwater observations of bluewater plankton: Logistics, techniques, and safety procedures for divers at sea. Limnol. Oceanogr. 20: 1045-1051

Harrison, W. G. (1978). Experimental measurements of nitrogen remineralization in coastal waters. Limnol. Oceanogr. 23: 684-694

Hobbie, J. E., Daley, R. J., Jasper, S. (1977). Use of nuclepore filters for counting bacteria by fluorescence microscopy. Appl. environ. Microbiol. 33: 1225-1228

Hollander, M., Wolfe, D. A. (1973). Nonparametric statistical methods. John Wiley \& Sons, New York

Honjo, S., Roman, M. R. (1978). Marine copepod fecal pellets: production, preservation and sedimentation. J. mar Res. 36: $45-57$

Jacobsen, T. R., Azam, F. (1984). Role of bacteria in copepod fecal pellet decomposition: colonization, growth rates and mineralization. Bull. mar. Sci. 35: 495-502

Johannes, R. E., Satomi, M. (1966). Composition and nutritive value of fecal pellets of a marine crustacean. Limnol. Oceanogr. 11. 191-197

Joiris, C., Billen, G., Lancelot, C., Daro, M. H., Mommaerts, A., Bertels, A., Bossicart, M., Nijs, J., Hecq, J. H. (1982). A budget of carbon cycling in the Belgian coastal zone: Relative roles of zooplankton, bacterioplankton and benthos in the utilization of primary production. Neth. J. Sea Res. 16: 260-275

Kirchman, D., Sigda, J., Kapuscinski, R., Mitchell, R. (1982). Statistical analysis of the direct count method for enumerating bacteria. Appl environ. Microbiol. 44: $376-382$

Knauer, G. A., Heber, D., Cipriano, F. (1982). Marine snow: Major site of primary production in coastal waters. Nature, Lond. 300: 630-631

Laycock, R. A. (1974). The detrital food chain based on seaweeds. I. Bacteria associated with the surface of Laminaria fronds. Mar. Biol. 25: 223-231

Linley, E. A. S., Newell, R. C. (1984). Estimates of bacterial growth yields based on plant detritus. Bull. mar. Sci. 35: 409-425

Linley, E. A. S., Newell, R. C., Bosma, S. A. (1981). Heterotrophic utilization of mucilage released during fragmentation of kelp (Ecklonia maxima and Laminaria pallida). I. Development of microbial communities associated with the degradation of kelp mucilage. Mar. Ecol. Prog. Ser. 4: $31-41$

Linley, E. A. S., Newell, R. C., Lucas, M. I. (1983). Quantitative relationships between phytoplankton, bacteria and heterotrophic microflagellates in shelf waters. Mar. Ecol. Prog. Ser. 12: 77-89

Mann, K. H. (1976). Decomposition of marine macrophytes. In: Anderson. J. M., Macfadyen, A. (ed.) The role of terrestrial and aquatic organisms in decomposition processes. Blackwell Sci. Pub., Oxford, p. 247-267

Paffenhofer, G.-A. (1973). The cultivation of an appendicularian through numerous generations. Mar. Biol. 22: 183-185

Pomeroy, L. R. (1984). Significance of microorganisms in 
carbon and energy flow in marine ecosystems. In: Klug, M. J., Reddy, C. A. (ed.) Current perspectives in microbial ecology. Am. Soc. Microbiol., Washington, D.C., p. 405-411

Pomeroy, L. R., Deibel, D. (1980). Aggregation of organic matter by pelagic tunicates. Limnol. Oceanogr. 25: $643-652$

Pomeroy, L. R., Hanson, R. B., McGllivary, P. A., Sherr, B. F., Kirchman, D., Deibel, D. (1984). Microbiology and chemistry of fecal products of pelagic tunicates: Rates and fates. Bull. mar. Sci. 35: 426-439

Porter, K. G., Feig, Y. S. (1980). The use of DAPI for identifying and counting aquatic microflora. Limnol. Oceanogr. 25: 943-948

Rodina, A. G. (1963). Microbiology of detritus of lakes. Limnol. Oceanogr. 8: 388-393

Shanks, A. L., Trent, J. D. (1980). Marine snow: Sinking rates and potential role in vertical flux. Deep Sea Res. $27 \mathrm{~A}$ : 137-143

Sherr, E. B., Sherr, B. F., Fallon, R. D., Newell, S. Y. (1986). Small, aloricate ciliates as a major component of the marine heterotrophic nanoplankton. Limnol. Oceanogr. 31: $177-183$
Silver, M. W., Shanks, A. L., Trent, J. D. (1978). Marine snow: Microplankton habitat and source of small-scale patchiness in pelagic populations. Science 201: 371-373

Silver, M. W., Gowing, M. M., Brownlee, D. C., Corless, J. O. (1984). Ciliated Protozoa associated with oceanic sinking detritus. Nature, Lond. 309: 246-248

Sorokin, Y. I. (1977). The heterotrophic phase of plankton succession in the Japan Sea. Mar. Biol. 41: 107-117

Strathmann, R. R. (1967). Estimating the organic carbon content of phytoplankton from cell volume or plasma volume. Limnol. Oceanogr. 12: 411-418

Stuart, V., Lucas, M. I., Newell, R. C. (1981). Heterotrophic utilization of particulate matter from the kelp Laminaria pallida. Mar. Ecol. Prog. Ser. 4: 337-348

Watson, S. W., Novitsky, T. J., Quinby, H. L., Valois, F. W. (1977). Determination of bacterial number and biomass in the marine environment. Appl. environ. Microbiol. 33: 940-946

Williams, P. J. LeB. (1981). Incorporation of microheterotrophic processes into the classical paradigm of the planktonic food web. Kieler Meeresforsch. (Sonderh.) 5: 1-28

This article was presented by Dr. S. Y. Newell; it was accepted for printing on July 11, 1986 